\title{
Mechanical Properties of High-Performance Concrete with Guinea Corn Husk Ash as Additive
}

\author{
${ }^{1 *}$ Odeyemi, S.O., ${ }^{2}$ Anifowose, M.A., ${ }^{1}$ Abdulwahab, R. and ${ }^{3}$ Oduoye, W.O. \\ ${ }^{1}$ Department of Civil and Environmental Engineering, Kwara State University, Malete, Nigeria \\ ${ }^{2}$ Department of Civil Engineering, The Federal Polytechnic Offa, Offa, Nigeria. \\ ${ }^{3}$ Department of Civil Engineering, Osun State University, Osogbo, Nigeria \\ *Corresponding author E-mail: samson.odeyemi@kwasu.edu.ng; +2348054147596
}

\begin{abstract}
Consideration on High Performance Concrete (HPC) has risen drastically because of the requirement for application of concrete volume with high strengths for construction work. In this study, the mechanical properties of HPC with Guinea Corn Husk Ash (GCHA) as supplement of cement was investigated. The proportioning of Ordinary Portland Cement (OPC) with GCHA is from $0-20 \%$. Design of the concrete mix was done to achieve a characteristic strength of 50 $\mathrm{N} / \mathrm{mm}^{2}$. The chemical composition of the GCHA was determined using X-ray Fluorescence (XRF). Slump and compacting factor of fresh HPC were determined. Concrete cubes (for compressive strength), beams (for flexural strength) and cylinder (for split tensile strength) samples were cast and cured in water for 7 - 56 days. Density, compressive, flexural, and split tensile strengths were determined on the hardened HPC and were further examined using SEM analysis. Compressive strength at 56 days showed that control and inclusion of $5 \%$ GCHA gave strength $56.85 \mathrm{~N} / \mathrm{mm}^{2}$ and $57.76 \mathrm{~N} / \mathrm{mm}^{2}$, respectively above the designed target strength of $56.56 \mathrm{~N} / \mathrm{mm}^{2}$ while inclusion of $10 \% \mathrm{GCHA}$ met characteristics strength of $50 \mathrm{~N} / \mathrm{mm}^{2}$. However, $5 \%$ GCHA-concrete had the highest flexural and split tensile strengths at 56 days of curing. Integration of $10 \% \mathrm{GCHA}$ as replacement of OPC would produce concrete of higher strengths compared to conventional HPC at longer curing age. Based on the SEM results, uniform distribution of filler was obtained at 10\% GCHA inclusion. At higher percentage of GCHA, resulting composite presents multiple and distinct grains with possible weak interfaces.
\end{abstract}

Keywords: Compressive strength, Flexural strength, Guinea Corn Husk Ash, High Performance Concrete, Split tensile strength

\section{Introduction}

High performance concrete (HPC) are in high demand because of its high strength, good workability, and better durability. The common strategy in increasing the strength of highperformance concrete is by lowering the water-cement ratio and increasing the cement content (Mahmud et al., 2016). HPC is a type of concrete that fulfils distinct performance and uniformity requirements which would not be accomplished by adopting conservative materials and standard mixing, placing, and curing practices (Rana et al., 2016). The focus on HPC has drastically risen because of the utilization of large volume of concrete, resulting to the growth in infrastructure such as Highways, Bridges, Buildings, Hydraulic Structures, and Industrial Structures (Choudhary et al., 2014). HPC possesses high durability, fluidity, workability, density, modulus of elasticity, dimensional stability, and compressive strength, self-compacting, easy mixing, low permeability, higher flexural strength, resistance to chemical attack, cost effectiveness, and environmental friendliness (Mondal and Banerjee (2017).

HPC concrete is usually produced with materials such as Ground Blast Furnace Slag, Fly Ash or Silica fume in addition to cement to achieve its requirement. The materials are mixed with 
Portland cement in varying proportions depending on the desired requirement (Choudhary et al., 2014).

This research was aimed at using Guinea Corn Husk Ash (GCHA) as fractional replacement of cement in HPC to improve the strength of the concrete. GCHA is obtained from the combustion of Guinea Corn Husk (GCH) either in a furnace (controlled temperature) or open burning (uncontrolled temperature). Akinloye et al., (2014) described GCHA as agricultural waste which is derived from the processing of guinea corn. Close to ten (10) million tonnes of guinea corn husk are roduced yearly in the world. About two (2) million tonnes of Guinea corn are harvested per annum in Nigeria (Akinloye et al., 2014). GCH are regarded as wastes by farmers and large quantities of the husks are burnt in preparation for another farming season (Adebayo et al., 2017). However, commercial use of guinea corn husk (with its ash) is the alternative solution to disposal and environmental problems caused by farmers through these wastes.

Ndububa and Nurudeen (2015) examined the influence of GCHA as fractional replacement for cement in concrete. The findings showed that GCHA meets the requirement of a pozzolan in accordance with standards and it was concluded that GCHA is a good pozzolan for normal concrete while the optimum replacement levels is between $5 \%-10 \%$. However, it was observed that much work have not been done on utilization of GCHA for production of concrete especially in Nigeria where large deposit of GCH can be found. Nonetheless, the study did not examine consistency and setting time of GCHA; flexural and split tensile strengths; Scanning Electron Microscopy (SEM) of hardened concrete; 56 days curing age and mechanical properties of HPC.

Subbulakshmi et al., (2014) studied the strength behaviour of HPC using silica fume, fibres and fly ash. The study revealed that $20 \%$ fly ash plus $10 \%$ silica fume possess better flexural, compressive and split tensile strengths than the control mix. Farzadnia et al., (2011) reviewed the combination of inorganic admixtures in binary, ternary and quaternary blended mortars in concrete. It was concluded that metakaolin, rice husk ash, silica fume, blast furnace slag, fly ash and palm oil fuel ash can improve the dry shrinkage, compressive, creep and tensile strength of concrete. Ismeik (2009) studied the influence of inorganic admixtures on the mechanical properties of HPC made from local materials. The findings showed that the optimum compressive and flexural strengths was observed at a replacement level of $10 \%$ for silica fume content and at $15 \%$ replacement of fly ash content.

A study by Kannan (2017) on HPC using silica fume and fly ash at 0 - 10\% replacement of silica fume and 10\% unchanging replacement of fly ash to investigate its mechanical properties at 7 and 28 days. The findings showed that the HPC containing $7.5 \%$ of silica fume produced compressive, split tensile and flexural strengths of $61.33 \mathrm{~N} / \mathrm{mm}^{2}, 5.83 \mathrm{~N} / \mathrm{mm}^{2}$ and $5.96 \mathrm{~N} / \mathrm{mm}^{2}$, respectively at 28 days when compared with conventional concrete. While HPC containing $7.5 \%$ of silica fume blended 10\% fly ash produced compressive, split tensile and flexural strengths of $57.33 \mathrm{~N} / \mathrm{mm}^{2}$, $5.19 \mathrm{~N} / \mathrm{mm}^{2}$ and $5.36 \mathrm{~N} / \mathrm{mm}^{2}$, respectively. Hence, it was evident that concrete containing silica fume alone attains higher strength than those containing silica fume with fly ash.

Magudeaswaran and Eswaramoorthi (2013) examined the mechanical properties on micro silica (silica fume) and fly ash as partial cement replacement. The study showed that $5 \%$ silica fume blended $10 \%$ fly ash gave maximum compressive strengths of $61.33 \mathrm{~N} / \mathrm{mm}^{2}$ at 28 days compared to $54 \mathrm{~N} / \mathrm{mm}^{2}$ for the control mix. The optimum replacement for the split tensile and flexural strengths were obtained at $15 \%$ silica fume blended $7.5 \%$ fly ash $\left(3.60 \mathrm{~N} / \mathrm{mm}^{2}\right)$ and $5 \%$ silica fume blended $2.5 \%$ fly ash $\left(9.91 \mathrm{~N} / \mathrm{mm}^{2}\right)$, respectively. Thus, HPC containing silica fume blended fly ash attained enough strength for structural use. 
Basavaraja et al., (2018) studied strength properties of HPC by means of ultra-fine fly ash and nano silica. Optimum compressive, split tensile and flexural strengths of $82.36 \mathrm{~N} / \mathrm{mm}^{2}, 5.51$ $\mathrm{N} / \mathrm{mm}^{2}$ and $82.36 \mathrm{~N} / \mathrm{mm}^{2}$, respectively was achieved at $10 \%$ of ultrafine fly ash blended $4.5 \%$ Nano-silica admixtures. This generated a higher strength when compared to conventional concrete. Banjare and Jaiswal (2017) determined the performance of Supplementary Cementitious Materials (SCM) on high strength concrete mixes with Fly ash, Metakaolin, Silica Fume and combinations of the ashes. The fulfilment of the compressive strength of the fly ash combined silica fume performed better than the control mix.

Hunchate et al., (2014) studied HPC incorporated with silica fume and superplasticizer. It was observed that the compressive strength increased as the proportion of the silica fume rises to $15 \%$. Likewise, as the proportion of cement replacement with silica fume rose, the workability of the HPC declined. Dembovska et al., (2017) studied the influence of pozzolanic additives on the strength development of HPC. In the study, silica fume (10\% by weight of cement) led to increase in bending and compressive strengths (108MPa) of the HPC at 56 days.

Sata et al., (2007) studied the influence of pozzolan obtained from waste materials on mechanical properties of high-strength concrete. Pulverized coal combustion fly ash (FA), Fuidized bed combustion fly ash (FB), Rice husk-bark ash (RHBA), and Palm oil fuel ash (POFA) were utilized in partly replacing Portland cement Type I to produce high-strength concrete. Their findings recommend that FA, FB, RHBA and POFA are suitable as substitutes to cement in the manufacture of high-strength concrete without altering the mechanical configuration of concrete.

Based on the previous research, it was observed that much work have not been done on utilization of GCHA for production of concrete and no study was found on utilization of GCHA in HPC (as of the time of completing this study in 2019). However, the study of Ndububa and Nurudeen (2015) on GCHA was limited to normal strength concrete of mix ratio 1:2:4 (water cement ratio of 0.65 ) with maximum strength of $26.27 \mathrm{~N} / \mathrm{mm}^{2}$ and maximum curing age of 28 days. This study examined the oxide compositions of GCHA; consistency and setting time of GCHA; fresh properties (slump and compacting factor) of HPC produced with GCHA; compressive, flexural and split tensile strengths of HPC produced with GCHA, and Scanning Electron Microscopy (SEM) of HPC produced with GCHA.

\section{Materials and Methods}

Materials used in this study are Dangote cement brand of OPC (Grade 42.5R) with specific gravity of 3.13; clean water; natural sand passing through sieve $4.75 \mathrm{~mm}$ and crushed stone of maximum diameter $12.5 \mathrm{~mm}$ both meeting the standard specified in BS 882 (1992); Paracel Superplasticizer which conformed to ASTM C494 (1999) was used and guinea corn husk ash (GCHA) with specific gravity of 2.80. The GCH were sourced from a milling store at Ijagbo, Oyun Local Government of Kwara State. The husks were burnt to ashes at a temperature of $650{ }^{0} \mathrm{C}$ by Thermolyne Furnace at Foundry and Forging Workshop, Mechanical Engineering Department, The Federal Polytechnic Offa. The ashes were further ground to finer particles with a milling machine and allowed to pass through sieve $90 \mu \mathrm{m}$ (micron). The GCH and GCHA are presented in Figures 1 and 2 while Table 1 shows the physical properties of the materials. 


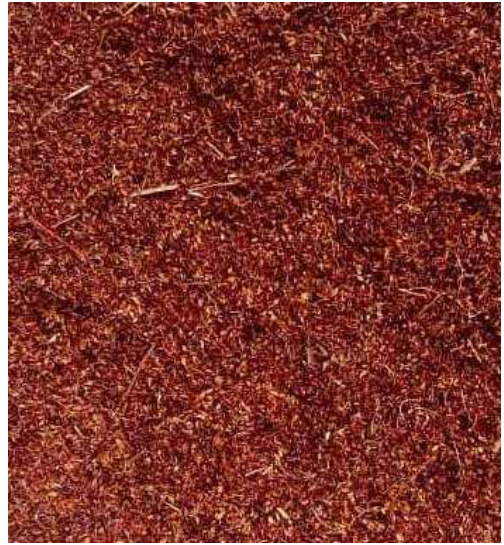

Figure 1: Guinea corn husks

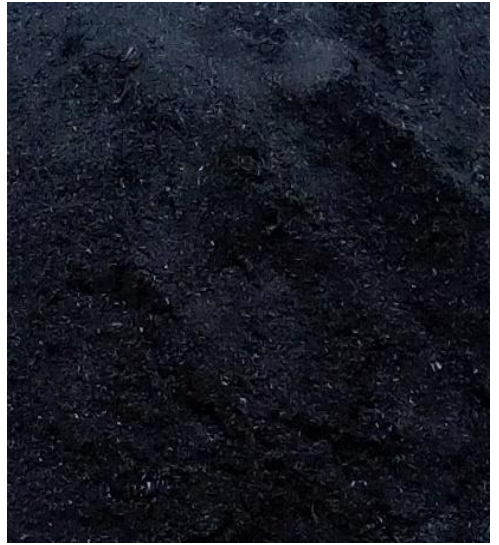

Figure 2: Guinea corn husks ash

The Fineness of OPC and GCHA were determined by sieving method, using sieve No. 9 (90 microns). The empty pan was weighed, and the weight was recorded. One hundred (100) grams of the cement sample was added to the weighing pan with the help of spatula. The new reading was taken as weight of empty pan plus 100 grams of cement. The cement was placed in the sieve and continuously sieved through circular and vertical motion for a period of 15 minutes. The residue left on the sieve was weighed and the weight was recorded (this weight shall not exceed $10 \%$ by weight of $100 \mathrm{~g}$ of cement used for OPC). The fineness was obtained using equation 1.

Fineness $=$ Percentage of Sample Re tained on Sieve

The fineness modulus was conducted in accordance with BS EN 933-1 (2012). The test sample was oven dried at temperature of $110 \pm 5^{\circ} C$ and weighed. The sample was sieved with a set of BS sieves and electric sieve shaker. On completion of sieving, the materials on each sieve were weighed. Cumulative weight passing through each sieve was calculated as a percentage of the total sample weight. Fineness modulus was obtained (using equation 2) by adding cumulative percentage of aggregates retained on each sieve and dividing the sum by 100 .

Fineness Modulus $=\frac{\text { Total Cummulative } \% \text { Re tained }}{100}$

Specific gravity of the materials was done in accordance with BS 1377:2 (1990). The samples were screened on BS sieve thoroughly to remove unwanted particles and other deleterious materials. The weight of empty bottle was recorded as $W_{1}$. The sample were filled into the bottle and weighed; the weight was recorded as $W_{2}$ (weight of bottle + dry sample). The bottle was filled gradually with distilled water to gauge mark, soon after the end of soaking, air entrapped and bubbles on the surface of the sample was removed by shaking the bottle and the weight was recorded as $W_{3}$ (weight of bottle + dry sample + distilled water), after which the bottle was emptied and oven dry. The bottle was then filled with distilled water to the gauge mark and weighed as $W_{4}$ (weight of bottle + distilled water). The specific gravity was obtained using equation 3 .

Specific Gravity $=\frac{w_{2}-w_{1}}{\left(w_{4}-w_{1}\right)-\left(w_{3}-w_{2}\right)}$ 
Table 1: Physical properties of materials

\begin{tabular}{ccccc}
\hline Test & \multicolumn{4}{c}{ Materials } \\
\cline { 2 - 5 } & OPC & GCHA & Fine Aggregate & Coarse Aggregate \\
\hline Fineness (\%) & 2.5 & 7 & 2.8 & 4.0 \\
$\begin{array}{c}\text { Fineness Modulus } \\
\text { (\%) }\end{array}$ & & & 2.67 & 2.69 \\
Specific Gravity & 3.13 & 2.80 & & \\
\hline
\end{tabular}

The replacement proportioning of OPC with GCHA were $0,5,10,15$ and 20\%. This range of replacements was in conformity to a previous study by Ndububa and Nurudeen (2015). Consistency and setting time of GCHA were determined in accordance with BS EN 196-3 2005+A1:2008 (2009) using the Vicat Apparatus. Slump and compacting factor were conducted on the fresh properties of HPC. Both tests conform to BS EN 12350-2 (2009) and BS EN 12350-4 (2009), respectively. One (1) percent of superplasticizer (SP) by mass of cement was added to the mix to improve the strength of the concrete thereby reducing the water cement ratio. Concrete mix design was adopted in accordance with COREN Mix Design Manual (2017) with a characteristic strength of $50 \mathrm{~N} / \mathrm{mm}^{2}$ and designed target mean strength of $56.56 \mathrm{~N} / \mathrm{mm}^{2}$. Forty-five (45) concrete cubes were produced ( 9 cubes for the control mix and 36 cubes for concrete with GCHA), Thirty (30) rectangular concrete beams ( 6 beams for the control mix and 24 beams specimen with GCHA) and a total number of 45 cylindrical concrete samples $(9$ cylindrical specimens for the control mix and 36 cylindrical specimens for concrete with GCHA) were formed. The concrete specimens were immersed in water for a period of 7,28 and 56 days. At the end of each curing ages, density of the concrete cubes was conducted in conformity to BS EN 12390-7 (2009). While compressive, flexural and split tensile strengths of the concrete cubes, beams and cylindrical samples were carried out in accordance to BS EN 12390-3 (2009), BS EN 12390-5 (2009) and BS EN 12390-6 (2000), respectively using Haida Universal Testing Machine (UTM) of $2000 \mathrm{kN}$ capacity at the Materials and Structures Laboratory, Department of Civil Engineering, Osun State University, Osogbo, Nigeria. The oxide composition of the GCHA was carried out at the National Agency for Science and Engineering Infrastructure (NASENI), Centre of Excellence, Nanotechnology and Advanced Material, Akure, Nigeria with the aid of Skyray EDX 3600B Energy Dispersive X-ray Fluorescence (XRF) Spectrometer. Scanning Electron Microscopy (SEM) was conducted on GCHA hardened concrete specimens. The SEM images were conducted at Kwara State University, Malete and measured on a Scanning Electron Microscope (ASPEX 3020) at $16.0 \mathrm{kV}$ accelerating voltage. The samples were coated with gold using Balzer's sputtering device before observing them in the microscope.

The mix proportions used are presented in Tables 2 to 4 .

Table 2: Mix proportions for concrete cube

\begin{tabular}{ccccccc}
\hline $\begin{array}{c}\text { W/C } \\
\text { Ratio }\end{array}$ & $\begin{array}{c}\text { Cement } \\
(\mathbf{k g})\end{array}$ & $\begin{array}{c}\text { GCHA } \\
(\mathbf{\%})\end{array}$ & $\begin{array}{c}\text { GCHA } \\
(\mathbf{k g})\end{array}$ & $\begin{array}{c}\text { SP } \\
(\mathbf{g})\end{array}$ & \multicolumn{2}{c}{ Aggregates } \\
\cline { 6 - 7 } & & & & & & $\begin{array}{c}\text { Fine }(\mathbf{k g}) \\
\text { Coarse } \\
(\mathbf{k g})\end{array}$ \\
\hline 0.31 & 24.60 & 0 & 0 & 246 & 19.35 & 35.85 \\
0.31 & 23.37 & 5 & 1.23 & 246 & 19.35 & 35.85 \\
0.31 & 22.14 & 10 & 2.46 & 246 & 19.35 & 35.85 \\
0.31 & 20.91 & 15 & 3.69 & 246 & 19.35 & 35.85 \\
0.31 & 19.68 & 20 & 4.92 & 246 & 19.35 & 35.85 \\
\hline
\end{tabular}


Table 3: Mix proportions for concrete beam sample

\begin{tabular}{|c|c|c|c|c|c|c|}
\hline \multirow{2}{*}{$\begin{array}{c}\text { W/C } \\
\text { Ratio }\end{array}$} & \multirow{2}{*}{$\begin{array}{c}\text { Cement } \\
\text { (kg) }\end{array}$} & \multirow{2}{*}{$\begin{array}{c}\text { GCHA } \\
(\%)\end{array}$} & \multirow{2}{*}{$\begin{array}{c}\text { GCHA } \\
\text { (kg) }\end{array}$} & \multirow{2}{*}{$\begin{array}{l}\text { SP } \\
\text { (g) }\end{array}$} & \multicolumn{2}{|c|}{ Aggregates } \\
\hline & & & & & Fine (kg) & $\begin{array}{c}\text { Coarse } \\
(\mathrm{kg})\end{array}$ \\
\hline 0.31 & 24.60 & 0 & 0 & 246 & 19.08 & 35.40 \\
\hline 0.31 & 23.37 & 5 & 1.23 & 246 & 19.08 & 35.40 \\
\hline 0.31 & 22.14 & 10 & 2.46 & 246 & 19.08 & 35.40 \\
\hline 0.31 & 20.91 & 15 & 3.69 & 246 & 19.08 & 35.40 \\
\hline 0.31 & 19.68 & 20 & 4.92 & 246 & 19.08 & 35.40 \\
\hline
\end{tabular}

Table 4: Mix proportions for concrete cylindrical sample

\begin{tabular}{ccccccc}
\hline $\begin{array}{c}\text { W/C } \\
\text { Ratio }\end{array}$ & $\begin{array}{c}\text { Cement } \\
(\mathbf{k g})\end{array}$ & $\begin{array}{c}\text { GCHA } \\
(\mathbf{\%})\end{array}$ & $\begin{array}{c}\text { GCHA } \\
(\mathbf{k g})\end{array}$ & $\begin{array}{c}\text { SP } \\
\mathbf{( g )}\end{array}$ & & \multicolumn{2}{c}{ Aggregates } \\
\hline 0.31 & 38.70 & 0 & 0 & 387 & 30.33 & 56.25 \\
0.31 & 36.76 & 5 & 1.94 & 387 & 30.33 & 56.25 \\
0.31 & 34.83 & 10 & 3.87 & 387 & 30.33 & 56.25 \\
0.31 & 32.89 & 15 & 5.81 & 387 & 30.33 & 56.25 \\
0.31 & 30.96 & 20 & 7.74 & 387 & 30.33 & 56.25 \\
\hline
\end{tabular}

\section{Results and Discussion} Oxides composition of GCHA

The oxide composition of the GCHA is presented in Table 5.

Table 5: Oxides composition of GCHA

\begin{tabular}{cc}
\hline Content & Percentage (\%) \\
\hline $\mathrm{SiO}_{2}$ & 66.06 \\
$\mathrm{Al}_{2} \mathrm{O}_{3}$ & 4.44 \\
$\mathrm{Fe}_{2} \mathrm{O}_{3}$ & 4.36 \\
$\mathrm{CaO}$ & 2.90 \\
$\mathrm{MgO}$ & 0.00 \\
$\mathrm{~K}_{2} \mathrm{O}$ & 10.79 \\
$\mathrm{Na}_{2} \mathrm{O}$ & 0.00 \\
$\mathrm{SO}_{3}$ & 1.74 \\
$\mathrm{Mn}$ & 0.05 \\
$\mathrm{Zn}$ & 0.42 \\
\hline
\end{tabular}

The summation of the oxides - $\mathrm{SiO}_{2}, \mathrm{Al}_{2} \mathrm{O}_{3}$, and $\mathrm{Fe}_{2} \mathrm{O}_{3}$, of GCHA used in this research, is $74.86 \%$ with silicon dioxide $\left(\mathrm{SiO}_{2}\right)$ possessing the maximum percentage of oxide composition. This fulfils the condition for a supplementary cementing material given in BS EN 197-1 (2011). In addition, the sum of the oxides - $\mathrm{SiO}_{2}, \mathrm{Al}_{2} \mathrm{O}_{3}$, and $\mathrm{Fe}_{2} \mathrm{O}_{3}$ of the GCHA, which is above $70 \%$ agrees with the previous finding by Ndububa and Nurudeen (2015).

\section{Consistency and setting time of OPC-GCHA}


The consistency and setting time results of the OPC-GCHA are presented in Figures 3 and 4 respectively.

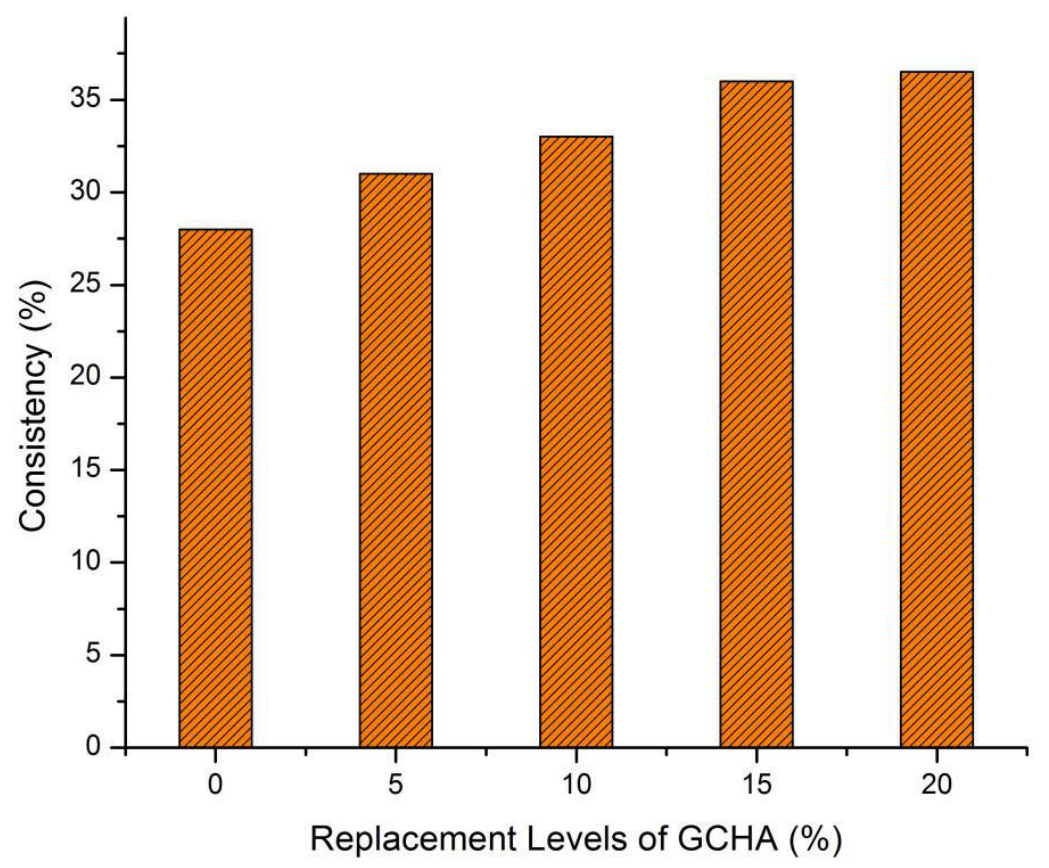

Figure 3: Consistency of OPC-GCHA HPC

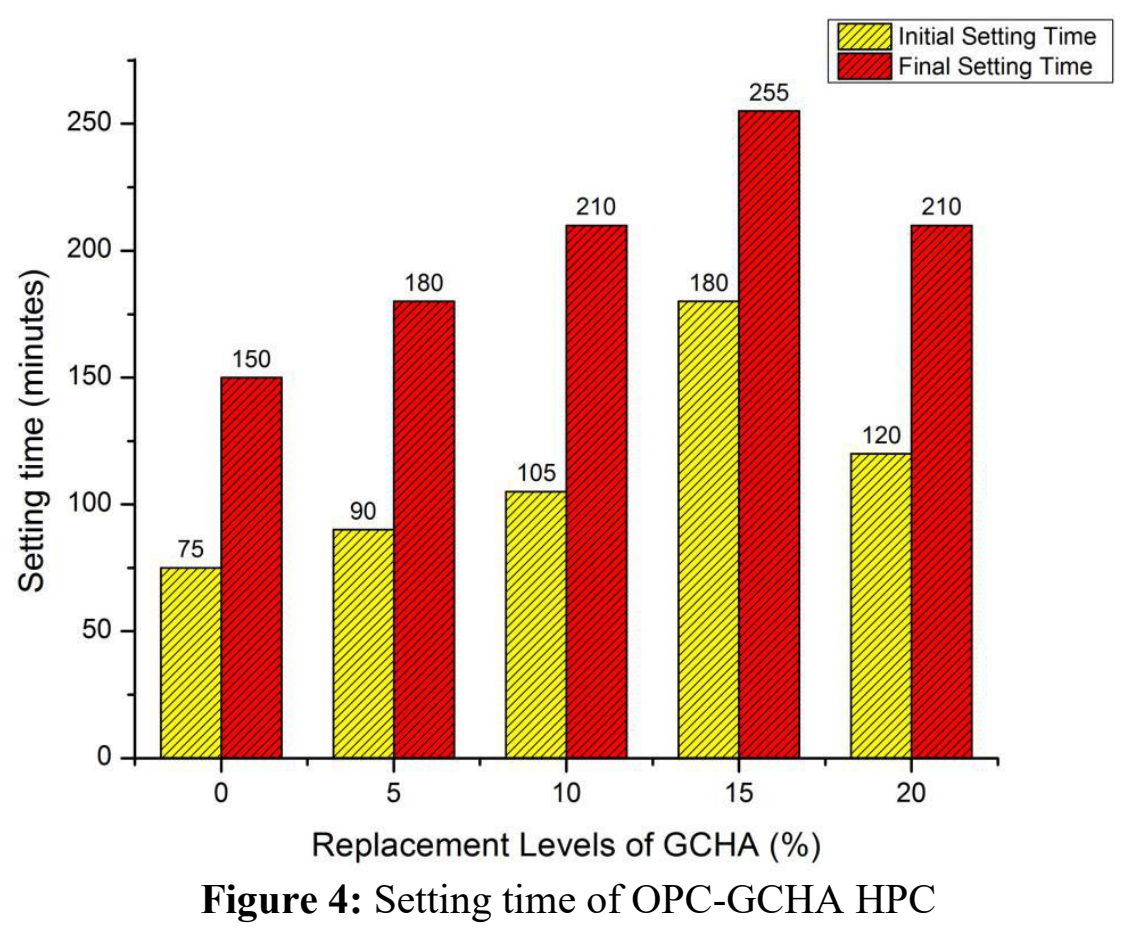

The results from Figure 3 shows that 20\% GCHA by weight of OPC have the highest consistency while $0 \%$ have the lowest consistency. However, as the ratio of replacement of OPC increased, the consistency also increased. It should be noted that the specific gravity of GCHA is lower than that of OPC, resulting in larger volume of GCHA compared with the OPC, since the OPC was replaced by mass. This led to addition of more water to form a paste for consistency for the different percentages of GCHA in the blended OPC (Adesanya and Raheem, 2009). ASTM 
$\mathrm{C} 150 / \mathrm{C} 150 \mathrm{M}$ (2012) recommends 45 minutes as the least for initial setting time and 375 minutes as the extreme for final setting time while BS EN 197-1 (2000) recommends 60 minutes as the least for initial setting time for 42.5R OPC. The outcome of the setting time (Figure 4) reveals that all percentage replacement (OPC/GCHA) conformed to the least initial time and highest final time specified by ASTM C150/C150M (2012). The behaviour of the consistency and setting correlates with the earlier study by Ige et al., (2017) and Anifowose et al., (2018).

\section{Workability of fresh concrete}

The results for the workability (slump and compacting factor) of fresh HPC are presented in Figures 5 and 6.

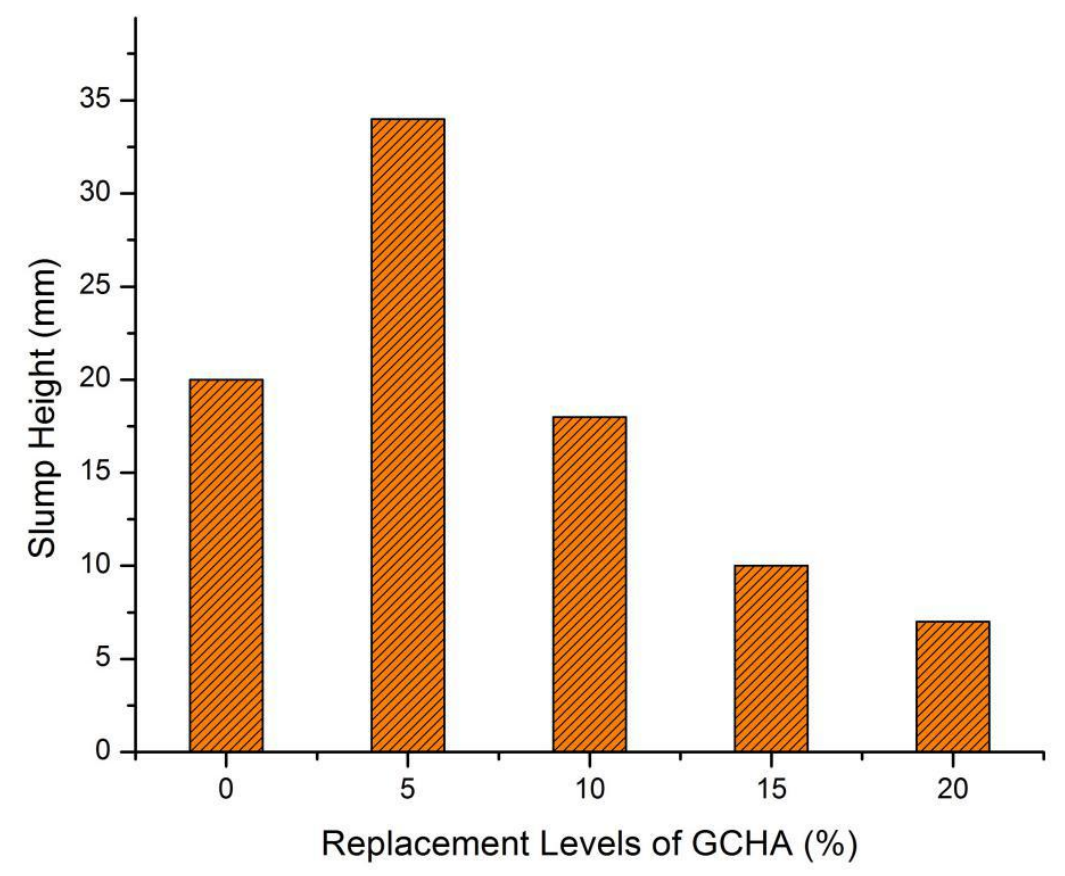

Figure 5: Slump of OPC-GCHA HPC

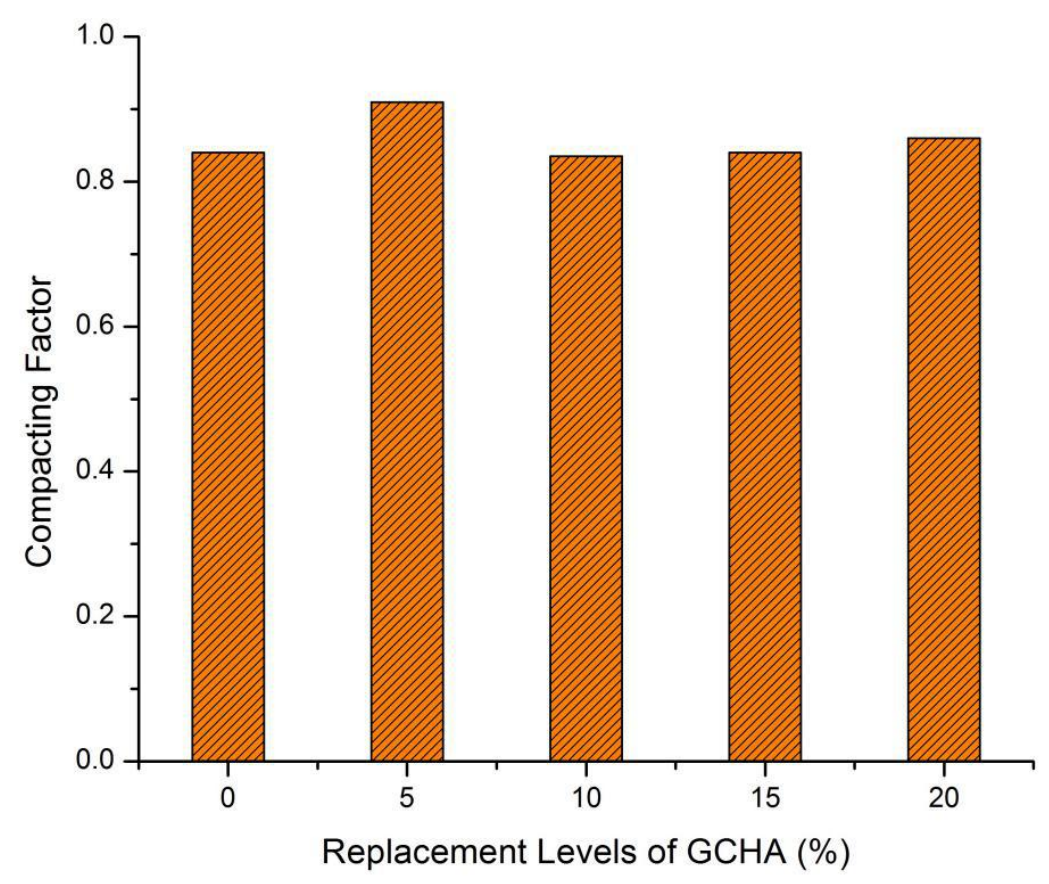


Figure 6: Compacting factor of OPC-GCHA HPC

From Figure 5, the slump height values reduced as the proportion of GCHA by weight of OPC surges. This shows that the concrete became stiff as the proportion of GCHA by weight of OPC increases. This agrees with the submission by Ige et al., (2018) that SCM absorb more water in concrete which makes it become less workable. The high demand for water as the GCHA content increases is as a result of the increased amount of silica in the mixture (Obilade, 2014). Nonetheless, the compacting factor value (Figure 6) reduced at 10\% replacement and afterwards increased at 15 and 20\%. Compacting factor is suitable for concrete of low workability (Shetty, 2000). The compacting factor values in Figure 6 fell within the minimum value of 0.70 and maximum value of 0.98 specified by BS EN 12350-4 (2009).

\section{Density of fresh concrete}

The mean density of the GCHA-HPC cubes conducted is as presented in Table 6.

Table 6: Density of Concrete Cubes

\begin{tabular}{cccc}
\hline \multirow{2}{*}{$\begin{array}{c}\text { Replacement of } \\
\text { GCHA }(\%)\end{array}$} & \multicolumn{3}{c}{ Mean Density $\left(\mathbf{K g} / \mathbf{m}^{\mathbf{3}}\right)$} \\
\cline { 2 - 4 } & 7 Days & 28 Days & 56 Days \\
\hline 0 & 2489 & 2607 & 2610 \\
5 & 2489 & 2578 & 2615 \\
10 & 2459 & 2419 & 2582 \\
15 & 2350 & 2359 & 2480 \\
20 & 2300 & 2330 & 2476 \\
\hline
\end{tabular}

The densities of all the concrete cubes formed is within the boundary of $2300 \mathrm{~kg} / \mathrm{m}^{3}-2615 \mathrm{~kg} / \mathrm{m}^{3}$ for structural concrete as specified in BS EN 12390-7 (2009). The density of the concrete declined as the proportion of GCHA increased and this corresponds to the study by Magudeaswaran and Eswaramoorthi (2013) on HPC. However, the density of the cubes increased with increase in curing age, which leads to improvement in unit weight due to prolongation of curing (rate of hydration). The maximum unit weight of $2615 \mathrm{~kg} / \mathrm{m}^{3}$ recorded at $5 \%$ GCHA signified the peak compressive strength obtained at 56 days curing.

\section{Compressive strength}

The compressive strength results of the GCHA-HPC at 7, 28 and 56 days are presented in Figure 7. 


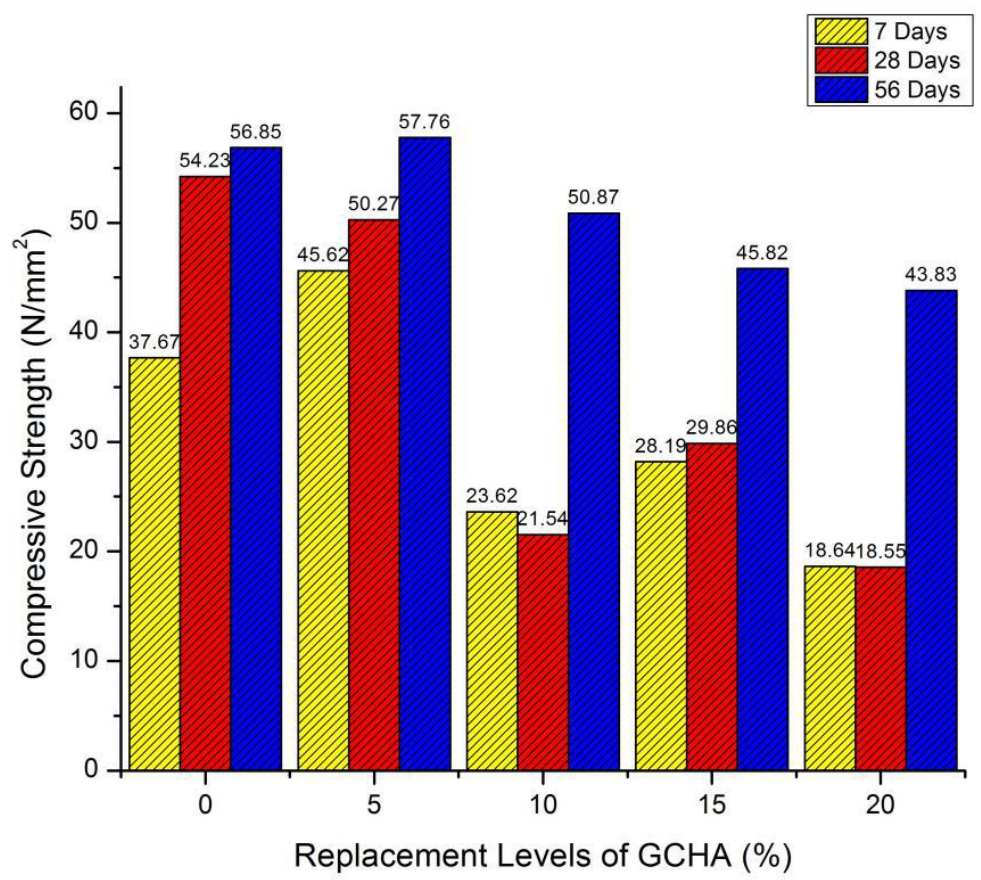

Figure 7: Compressive strength of OPC-GCHA HPC

The compressive strength results at 7 days curing shows that the control and 5\% GCHA met the least required compressive strength of $36 \mathrm{~N} / \mathrm{mm}^{2}$ for concrete grade 50 as contained in BS 8110-2 (1985) while the strength of 10\% GCHA, 15\% GCHA and 20\% GCHA are below the required strength. Likewise, at 28 days of curing, the compressive strength of $0 \%$ GCHA and 5\% GCHA met the least required compressive strength of $50 \mathrm{~N} / \mathrm{mm}^{2}$ for concrete grade 50 as contained in BS 8110-2 (1985) while the strength of 10\% GCHA, 15\% GCHA and 20\% GCHA falls below the required strength. At 56 days curing age, the compressive strength of the control and 5\% GCHA is above the designed target mean strength of $56.56 \mathrm{~N} / \mathrm{mm}^{2}$ while the compressive strength of $10 \%$ GCHA met the characteristics strength of $50 \mathrm{~N} / \mathrm{mm}^{2}$ but that of $15 \%$ GCHA and $20 \%$ GCHA falls below the designed target mean strength and characteristics strength. Nonetheless, the findings reveal that the compressive strength of concrete rises with increase in curing age and 5\% GCHAconcrete had the highest strength of $57.76 \mathrm{~N} / \mathrm{mm}^{2}$. This is followed by the control $\left(56.85 \mathrm{~N} / \mathrm{mm}^{2}\right)$, $10 \%$ GCHA $\left(50.87 \mathrm{~N} / \mathrm{mm}^{2}\right), 15 \%$ GCHA $\left(45.82 \mathrm{~N} / \mathrm{mm}^{2}\right)$, and $20 \%$ GCHA $\left(43.83 \mathrm{~N} / \mathrm{mm}^{2}\right)$.

Since SCM in concrete tends to gain strength at a longer curing age, the optimum GCHA that conforms to the characteristic compressive strength of $50 \mathrm{~N} / \mathrm{mm}^{2}$ is $5 \%$ and $10 \%$ GCHA replacement. The highest compressive strength $\left(57.76 \mathrm{~N} / \mathrm{mm}^{2}\right)$ obtained at $5 \%$ GCHA agrees and corresponds to the optimum replacement of GCHA reported by Ndububa and Nurudeen (2015) for use in concrete production. However, the study of Ndububa and Nurudeen (2015) was limited to normal concrete with maximum strength of $26.27 \mathrm{~N} / \mathrm{mm}^{2}$ (obtained at $5 \%$ GCHA), compressive strength and maximum curing age of 28 days.

\section{Flexural strength}

Results of the flexural strength of GCHA-HPC at 7, 28- and 56-days curing are presented in Figure 8 . 


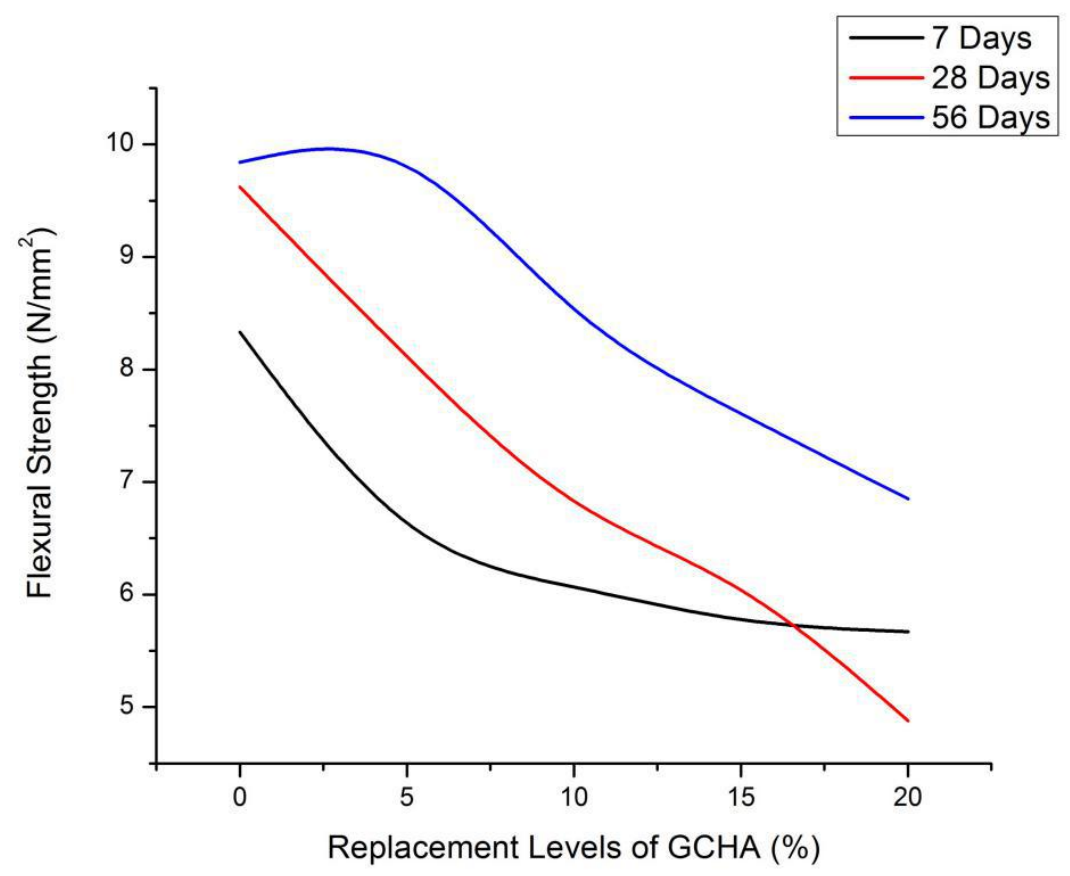

Figure 8: Flexural Strength of OPC-GCHA HPC

The outcome reveal that the flexural strength improved as the curing age increased. It was further observed that 5\% GCHA have the peak flexural strength at 56 days of curing unlike 28th day and 7 days where the conventional concrete has the peak strength. Nonetheless, 7 days flexural strength of $20 \%$ GCHA-Concrete was higher than that of 28th day curing. This is an indication of a drop in strength at 28th day which later improved at 56 days of curing age. At 56 days, 5\% GCHA provides the highest flexural strengths which negates the optimum replacement reported by Ismeik (2009) and Subbulakshmi et al., (2014). This is due to the difference in the SCM used in this research as compared to the one used by the Authors.

\section{Split tensile strength}

The split tensile strength result on GCHA-HPC at 7, 28- and 56-days curing are presented in Figure 9. 


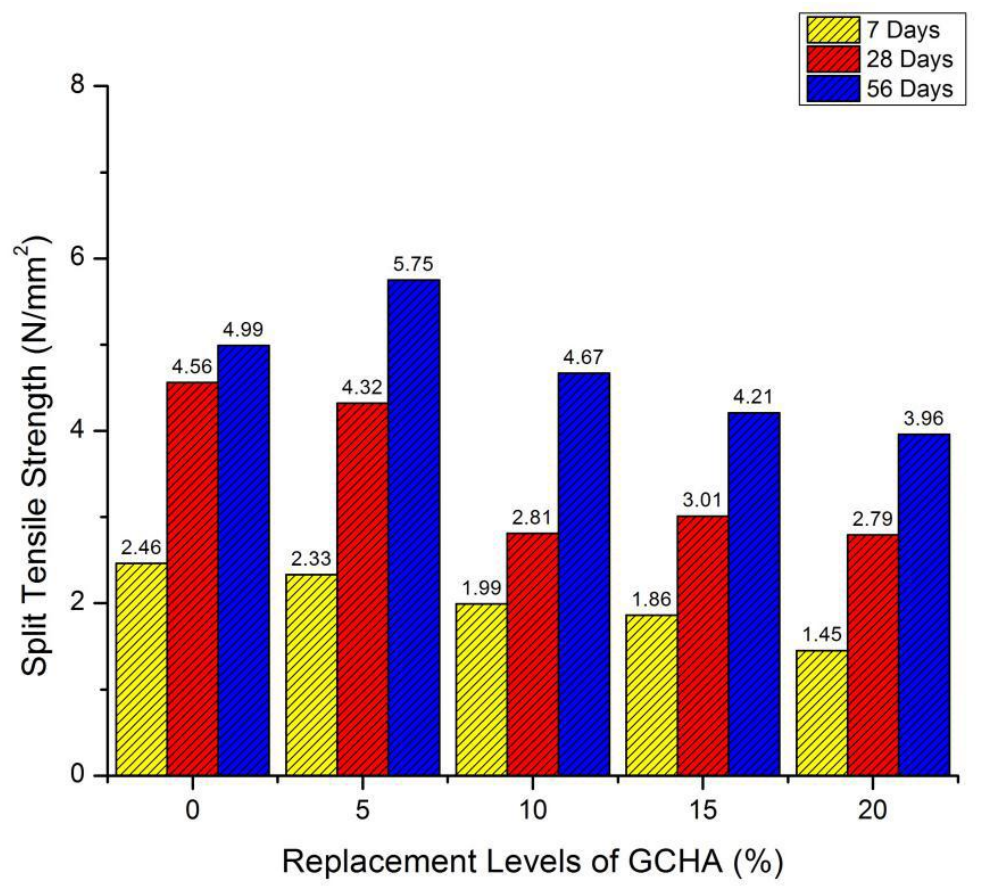

Figure 9: Split Tensile Strength of OPC-GCHA HPC

Just as observed in the flexural strength, the results shown in Figure 9 reveal that the split tensile strength increased as the curing age increased. It was also observed that 5\% GCHA replacement gave the highest splitting strength at 56 days of curing unlike 28th day and 7th day results where the conventional concrete had the highest strength. However, GCHA did not perform better in terms of optimum replacement of cement in HPC when compared with fly ash plus silica fume, silicafume and flyash, silicafume blended flyash, and micro silica (silica fume) blended fly ash used by Subbulakshmi et al., (2014), Ismeik (2009), Kannan (2017) and Magudeaswaran and Eswaramoorthi (2013), respectively.

\section{Microstructure of HPC}

The SEM images were measured and presented in Figures 10a-e.

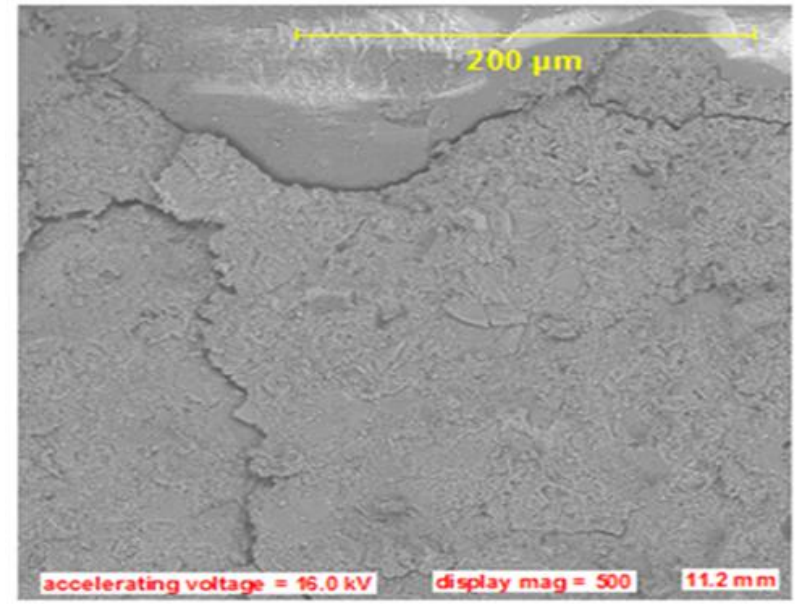

(a) $0 \%$ GCHA Inclusion

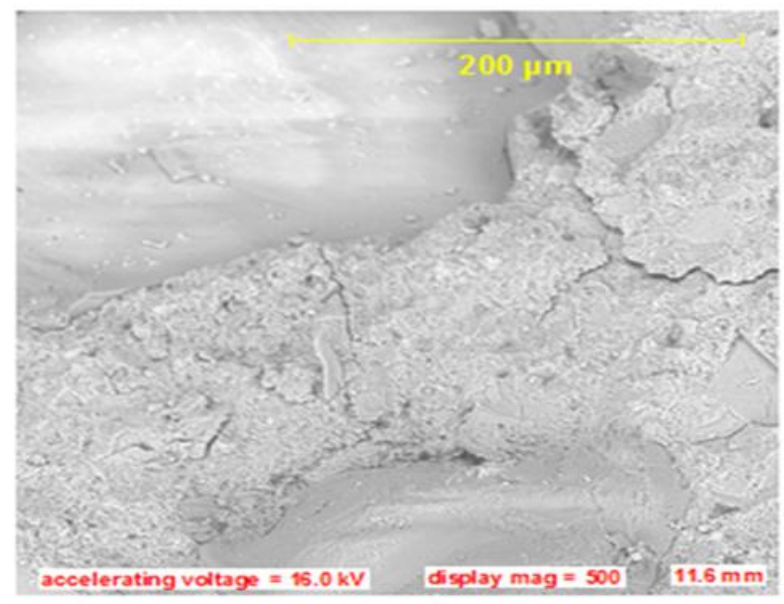

(b) 5\% GCHA Inclusion 


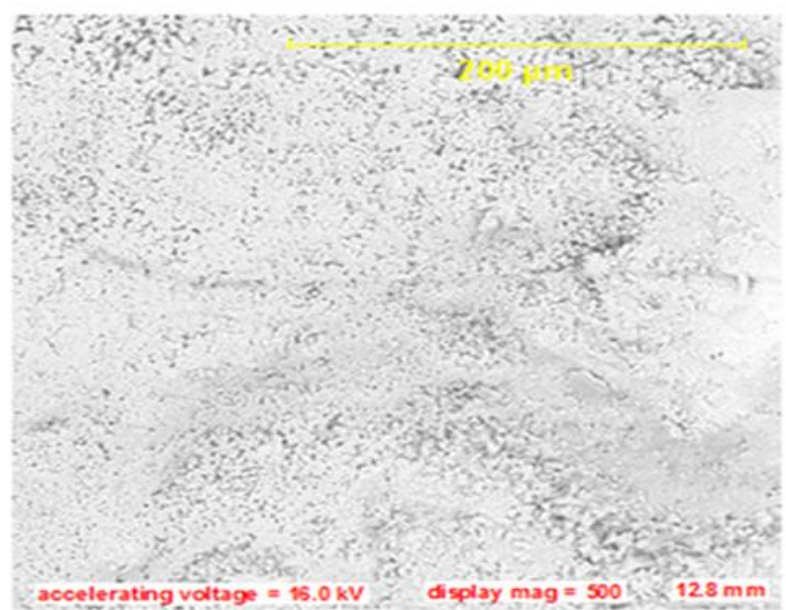

(c) 10\% GCHA Inclusion

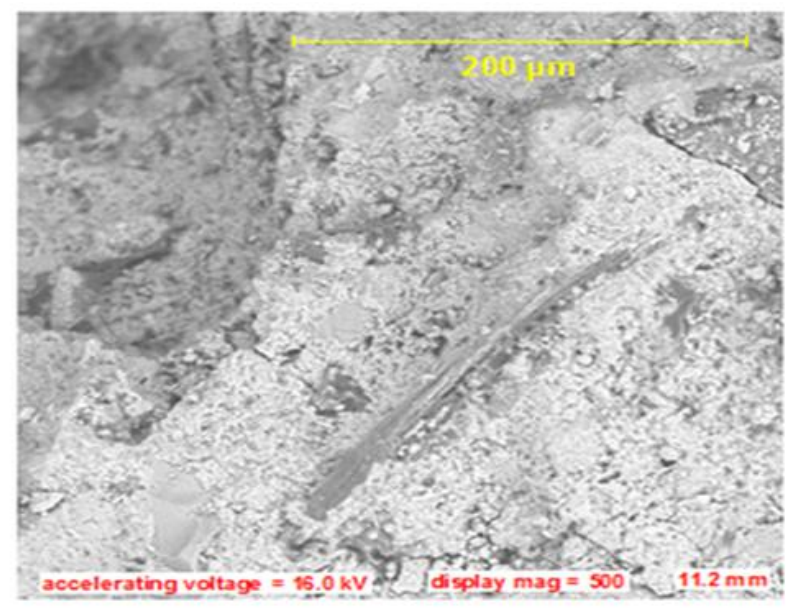

(d) $15 \%$ GCHA Inclusion

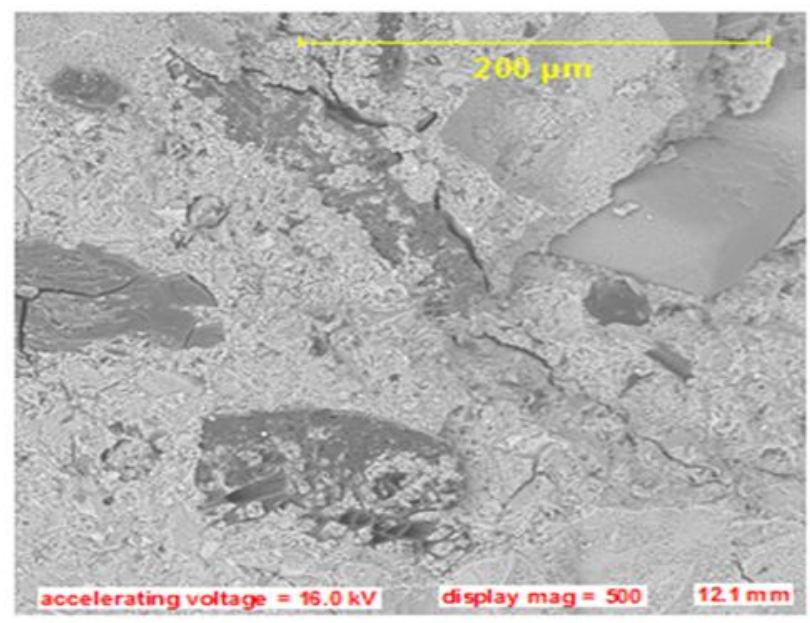

(e) $20 \%$ GCHA Inclusion

Figure 10: SEM Images of OPC-GCHA HPC

From the SEM micrographs in Figure 10, best uniform distribution of filler was obtained at $10 \%$ GCHA inclusion. At higher percentage of GCHA, resulting composite presents multiple and distinct grains with possible weak interfaces. These weak interfaces can provide weakness to the overall mechanical properties of the composite. On the other hand, the GCHA inclusion is expected to influence the mechanical properties of the composite with optimum values expected at $10 \%$ GCHA after 56 days curing. These improved properties can be because of crack deflection/impediment by the GCHA filler at the appropriate content.

The SEM results thus corroborates the results obtained from the compressive, flexural, and split tensile strength tests which reveals that OPC-GCHA HPC will perform optimally when GCHA is used as a replacement for OPC up to $10 \%$.

\section{Conclusion}

The following inferences were made from the study:

i. Guinea Corn Husk Ash meets the requirement for pozzolanic materials.

ii. All proportions of replacement of OPC with GCHA considered in the study meets the requirement for minimum initial and maximum final setting time for OPC.

iii. Concrete becomes stiff (less workable) as percentage of GCHA increases.

iv. Up to 5\% GCHA and 10\% GCHA replacement can be used for production of concrete grade 50 provided the minimum curing days is 56 days. 
v. $10 \%$ GCHA is recommended as the optimum replacement since it meets the $50 \mathrm{~N} / \mathrm{mm}^{2}$ characteristics strength at 56 days curing age.

\section{Acknowledgement}

The Authors acknowledge the input of the academic staff in the Department of Civil and Environmental Engineering, Kwara State University, Malete.

\section{References}

Adebayo, V. B., Adebayo, T. D. and Popoola, O. O. (2017). Effects of guinea corn husk ash and lime mixtures on lateritic soil for highway construction, Journal of Multidisciplinary Engineering Science and Technology (JMEST), 4(10): 8375-8381.

Adesanya, D. A. and Raheem, A. A. (2009). Development of corn cob ash blended cement, Construction and Building Materials, 23(1): 347-352. Doi: 10.1016/j.conbuildmat.2007.11.013

Akinloye, S. A., Bankole, G. M. and Medubi, A. (2014). Effect of lime-guinea corn husk ash on the engineering properties of lateritic soil, EJGE, 19: 17693-17699.

Anifowose, M. A, Ige, J. A, Yusuf, A. L, Adebara, S. A. and Abdulkarim, A. A. (2018). Physiochemical assessment of Rice Husk Ash (RHA) Blended Calcium Chloride $\left(\mathrm{CaCl}_{2}\right)$ as supplementary cementing materials, ANNALS of Faculty Engineering HunedoaraInternational Journal of Engineering, 16(4): 111-114.

ASTM C150/C150M (2012). Standard Specification for Portland Cement, American Society for Testing and Materials (ASTM International), West Conshohocken, PA 19428-2959, United States, pp.467-471.

ASTM C494 (1999). Standard Specification for Chemical Admixtures for Concrete, American Society for Testing and Materials (ASTM International), West Conshohocken, PA 194282959, United States.

Banjare, A. and Jaiswal, S. K. (2017). Influence of supplementary cementitious materials on high strength concrete, International Journal for Scientific Research \& Development, 5(10): 695697.

Basavaraja, R., Somasekharaiah, H. M. and Gadag, P. R (2018). Study on strength properties of high-performance concrete using ultra-fine fly ash and Nano silica, International Research Journal of Engineering and Technology (IRJET), 5(1): 814-823.

BS EN 12350-2 (2009). Testing Fresh Concrete - Slump Test, British Standards, London, W4 4AL, UK, Standards Policy and Strategy Committee.

BS EN 12350-4 (2009). Testing Fresh Concrete - Degree of Compactability, British Standards, London, W4 4AL, UK, Standards Policy and Strategy Committee.

BS EN 12390-3 (2009). Testing Hardened Concrete - Compressive Strength of Test Specimens, British Standards, London, W4 4AL, UK, Standards Policy and Strategy Committee.

BS EN 12390-5 (2009). Testing Hardened Concrete - Flexural Strength of Test Specimens, British Standards, London, W4 4AL, UK, Standards Policy and Strategy Committee.

BS EN 12390-6 (2000). Testing Hardened Concrete - Tensile Splitting Strength of Test Specimens, British Standards, London, W4 4AL, UK, Standards Policy and Strategy Committee, (Amended 17th November, 2004).

BS EN 12390-7 (2009). Testing Hardened Concrete - Density of Hardened Concrete, British Standards, London, W4 4AL, UK, Standards Policy and Strategy Committee.

BS EN 196-3 2005+A1:2008 (2009). Methods of Testing Cement-Determination of Setting Time and Soundness, British Standards, London, W4 4AL, UK, Technical Committee B/516.

BS EN 197-1 (2011). Cement-Composition, Specifications and Conformity Criteria for Common Cements, British Standards, London, W4 4AL, UK, Standards Policy and Strategy Committee. 
BS EN 933-1 (2012). Tests for Geometrical Properties of Aggregates - Part 1: Determination of Particle Size Distribution - Sieving Method, British Standards, London, W4 4AL, UK, Standards Policy and Strategy Committee.

BS 882 (1992). Specification for Aggregates from Natural Sources for Concrete, British Standards, London, W4 4AL, UK, Standards Policy and Strategy Committee (Amended 6th March, 2002).

BS 1377:2 (1990). Methods of Test for Soil for Civil Engineering Purposes. British Standards, London, W4 4AL, UK, Standards Policy and Strategy Committee.

BS 8110-2 (1985). Structural Use of Concrete, Code of Practice for Design and Construction, British Standards, London, W4 4AL, UK, Civil Engineering and Building Structures Standards Committee (Amended May, 1989).

Choudhary, S., Bajaj, R. and Sharma, R.K. (2014). Study of high-performance concrete, Journal of Civil Engineering and Environmental Technology, 1(5): 109-113.

COREN Mix Design Manual (2017). Concrete Mix Design Manual "First Edition", Council for The Regulation of Engineering In Nigeria, Special Publication NO. COREN/2017/016/RC.

Dembovska, L., Bajarea, D., Pundieneb, I. and Vitola, L. (2017). Effect of pozzolanic additives on the strength development of high-performance concrete, Procedia Engineering, 172: 202210. Doi: 10.1016/j.proeng.2017.02.050

Farzadnia, N., Ali, A. A. A. and Demirboga, R. (2011). Incorporation of mineral admixtures in sustainable high-performance concrete, International Journal of Sustainable Construction Engineering \& Technology, 2(1): 44-56.

Hunchate, S. R., Chandupalle, S., Ghorpode, V. G. and Venkata-Reddy, T. C. (2014). Mix design of high-performance concrete using silica fume and superplasticizer, International Journal of Innovative Research in Science, Engineering and Technology, 3(3): 10735-10742.

Ige, J. A., Anifowose, M. A., Odeyemi, S. O., Adebara, S. A. and Oyeleke, M. O. (2018). Assessment of Rice Husk Ash (RHA) and Calcium Chloride $\left(\mathrm{CaCl}_{2}\right)$ on compressive strength of concrete grade 20, International Journal of Engineering Research in Africa (JERA), 40: 22-29. Doi: 10.4028/www.scientific.net/JERA.40.22

Ige, J. A., Anifowose, M. A., Oyeleke, M. O., Bakare, S. B. and Akinjobi, T. F. (2017). Physiochemical assessment of Groundnut Shell Ash (GSA) blended Calcium Chloride $\left(\mathrm{CaCl}_{2}\right)$ as supplementary cementing material, ACTA TECHNICA CORVINIENSIS-Bulletin of Engineering Journal, 10(3): 155-158.

Ismeik, M. (2009). Effect of mineral admixtures on mechanical properties of high strength concrete made with locally available materials, Jordan Journal of Civil Engineering, 3(1): 78-90.

Kannan, S. U. (2017). Experimental investigation on high performance concrete using silicafume and flyash, International Journal of Engineering Research and Development, 13(10): 42-49.

Magudeaswaran, P. and Eswaramoorthi, P. (2013). Experimental investigations of mechanical properties on micro silica (silica fume) and fly ash as partial cement replacement of highperformance concrete, IOSR Journal of Mechanical and Civil Engineering (IOSR-JMCE), 6(4): 57-63.

Mahmud, H. B., Bahri, S., Yee, W. Y. and Yeap, Y. T. (2016). Effect of rice husk ash on strength and durability of high strength-high performance concrete, International Journal of Civil \& Environmental Engineering, 10(3): 390-395. Doi.org/10.5281/zenodo.1123585

Mondal, S. and Banerjee, S. (2017). High strength \& high-performance concrete, International Journal of Civil Engineering and Technology (IJCIET), 8(6): 782-786.

Ndububa, E. E. and Nurudeen, Y. (2015). Effect of guinea corn husk ash as partial replacement for cement in concrete, IOSR Journal of Mechanical and Civil Engineering (IOSR-JMCE,) 12(2): 40-45. Doi: 10.9790/1684-12214045 
Obilade, I. O. (2014). Use of rice husk ash as partial replacement for cement in concrete, International Journal of Engineering and Applied Sciences, 5(4): 11-16.

Rana, S. Tiwari, A. and Srivastava, A. K. (2016). High performance concrete and its applications in the field of civil engineering construction, International Journal of Current Engineering and Technology, 6(3): 982-985.

Sata, V., Jaturapitakkul, C. and Kiattikomol, K. (2007). Influence of pozzolan from various byproduct materials on mechanical properties of high-strength concrete, Construction and Building Materials, 21(7): 1589-1598. Doi: 10.1016/j.conbuildmat.2005.09.011

Shetty, M. S. (2000). Concrete Technology: Theory and Practice, S.Chand and Company Ltd., Ram Nagar, New Delhi.

Subbulakshmi, T., Vidivelli, B. and Nivetha, K. (2014). Strength behaviour of high-performance concrete using fibres and industrial by products, International Journal of Engineering Research \& Technology (IJERT), 3(8): 1219-1224. 